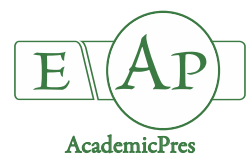

\title{
The Eggplant Yield and Fruit Composition as Affected by Genetic Factor and Biostimulant Application
}

\author{
Alicja POHL, Aneta GRABOWSKA, Andrzej KALISZ, \\ Agnieszka SĘKARA*
}

University of Agriculture in Krakow, Faculty of Biotechnology and Horticulture, 29 Listopada 54, 31-425, Krakow, Poland; ala_pobl@o2.pl; aneta.grabowska@urk.edu.pl; andrzej.kalisz@urk.edu.pl; agnieszka.sekara@urk.edu.pl (*correspondingauthor)

\begin{abstract}
Consumer demands regarding eggplant fruits are focused on perfect shape, color, and taste but nutritional and bioactive quality has also become important with rising awareness of food related health. On the other hand, producers value modern cultivars' earliness, high-yielding, stress-tolerance, and high overall fruit quality. We attempt to link these two standpoints through combining modern hybrids cultivated in the open field of temperate climatic zone with biostimulant application to increase the dynamics of yielding and the quality of fruits. The aim of our research was the determination of the genotypicdependent response of eggplant (Solanum melongena L.) to Ascophyllum nodosum standardized extract (Göemar BM-86) application in field conditions of Poland, with respect to the most important characteristics linked to yield quality and plant stress status. The early and total yield of investigated hybrids was affected by biostimulant application, and this dependence was confirmed statistically for most of the treatments. The increase of 'Epic' $F_{1}$ and 'Flavine' $F_{1}$ yield potential through Göemar BM-86 application was linked to higher fruit number harvested from the plants, while 'WA 6020' $F_{1}$ led to greater fruit weight. Investigated hybrids responded differently to biostimulant treatment with respect to dietary and pro-health value of fruits. Generally, the content of soluble sugar, anthocyanins, and mineral elements as well as was antioxidant activity of fruits were positively affected by biostimulant application. This tendency was statistically confirmed for several experimental treatments. Presented results give a new perspective on seaweed-based biostimulants as elicitors of crop's self defense mechanisms as well as modulators of fruit setting, productivity and bioactive compounds accumulation in eggplant.
\end{abstract}

Keywords: Ascophyllum nodosum; hybrids; Solanum melongena; stress; yield quality

\section{Introduction}

The biochemical composition of vegetables is the output of interaction between cultivation environment and genotypic constitution (San José et al., 2013). Although many investigations were performed recently regarding multidirectional action of different biostimulants in horticultural production, few were focused on berry producing vegetables, like eggplant and other Solanaceae crops. Moreover, few studies have been performed to investigate the changes in eggplant yielding and fruit chemical composition in the following seasons of field cultivation (Mennella et al., 2010; Raigón et al., 2010; San José et al., 2014).

Intensive breeding in eggplant resulted in successful market introduction of high yielding hybrids adapted to greenhouse cultivation, as well as to field production in less favouring environment (Rodríguez-Burruezo et al., 2008;
Sękara et al., 2016). Among morphological, physiological and qualitative characteristics of modern cultivars, fruit color, size, and shape are mostly forged to consumer preferences. Although many commercial groups were established, for example black, violet, pink, green, or white in color, uniform or striped regarding pattern on the peel, round to very elongated in shape, from miniature to large. In North America and Europe, eggplants with dark purple, oval or elongated, large fruits are the most popular group of cultivars, named 'western eggplants' (Sekara et al., 2010; Kumar et al., 2008; Cericola et al., 2013). In addition to morphological diversity, eggplant fruits are characterized by variation in secondary metabolites that influence fruit quality.

Eggplant is an important source of phenolic, vitamins and minerals with antioxidant, anti-microbial, hepatoprotective, and cardio-protective properties However, Davis (2009) reported a degradation of preferred nutrient composition of the vegetables, which comes because of selection for yield, perfect appearance and long 
930

shelf life in modern breeding programs. One way to solve this situation in eggplant breeding is through the hybridizing genotypes of high genetic distance (RodríguezBurruezo et al., 2008). Another proposal is the utilization of environmental-friendly practices to improve fruit quality, especially secondary metabolites content.

Biostimulant application in crops is intensively investigated as pro-ecological solution for modern agriculture. The concept of biostimulants was formulated at the end of $20^{\text {th }}$ century and has been continuously developed. The underlying scientific and utilitarian significance of the idea was described in recent review publications. The precise definition was formulated to distinguish biostimulants from the existing legislative products, and the main categories of biostimulants, including seaweed extracts, were specified (Brown and Saa, 2015; Colla and Rouphael, 2015; Du Jardin, 2015; Yakhin et al., 2017). Seaweeds are green, brown and red marine macro algae. Extracts of brown seaweeds (Phaeophyta), primarily Ascophyllum nodosum, Ecklonia maxima, Macrocystis pyrifera and Durvillaea potatorum are widely used in horticulture although reports on their effectiveness are inconclusive (Khan et al., 2009).

Among growth-promoting effects of seaweeds application, the amelioration of crop tolerance to abiotic stresses such as salinity, extreme temperatures, nutrient deficiency and drought is underlined. Investigations performed on Solanaceae crops, so far, demonstrated in tomato: enhanced seed germination, alleviated $\mathrm{Fe}, \mathrm{Mn}$, and $\mathrm{Zn}$ uptake, increased chlorophyll content, increased yield (Dobromilska et al., 2008; Khan et al., 2009; HernándezHerrera et al., 2014). Seaweed extract spraying increased fruit yield and improved chemical composition with respect to ascorbic acid and chlorophyll was demonstrated in pepper (Arthur et al., 2003; Manna et al., 2012), while increased in seed germination, vegetative growth and yield was reported for eggplant (Abd El-Gawad and Osman, 2014; Rao and Chatterjee, 2014; Pohl et al., 2018). Activation of crop's self defense mechanisms is the most frequently cited benefit of biostimulant application, caused by activation of soil-soil microorganisms-plant interaction, root growth, $\mathrm{N}$ and $\mathrm{P}$ uptake, and improved plant nutritional status (Yakhin et al., 2017). However, some preparations based on seaweed extract have more specific action addressed for particular species and growth phases. Göemar BM-86 (Arysta LifeScience North America, LLC) is an example of standardized $A$. nodosum extract enriched in macro- and microelements, which can improve the plant nutritional status, flowering and fruit setting. Standardized formula of preparation from leading companies ensures consistent product quality and leads to repeatability of scientific investigations on the results and mechanisms of their action (Sharma et al., 2014; Yakhin et al., 2017).

Basing on references cited we performed experiments focused on the genotypic-dependent response of eggplant cultivated in field conditions of Poland to Göemar BM-86 application. Warm-climate vegetable, like eggplant, meets multidirectional stress factors when growing in temperate climate zone. We hypothesized that biostimulant dedicated for flowering crops improves the yield amount, earliness, and fruit quality in the genotypic-dependent manner. We analyzed the most important parameters for yield quality, pro-health value of fruits as well as characterizing stressdependent antioxidant status of plants.

\section{Materials and Methods}

Biological material, cultural practices, and experimental layout The biological material included six hybrids of eggplant (Solanum melongena L.): 'Cristal' $F_{1}$ (Semillas Fito S.A.), 'Epic' $F_{1}$ (Seminis Vegetable Seeds), 'Flavine' $F_{1}$ (Gautier Semences), 'Gascona' $F_{1}$ (Gautier Semences), 'Onyx' $F_{1}$ (Semillas Fito S.A.), 'WA 6020' $\mathrm{F}_{1}$ (Western Seed International BV). Hybrids were selected on a base of preliminary studies evaluating their performance in field cultivation under temperate climate conditions (Sękara et al., 2010; Pohl et al., 2018), determined by earliness, vigour, and yield potential of the plants. Moreover, the diversity of colour and shape of the fruits were also considered at the point of cultivar selection (Fig. 1). The biostimulant Göemar BM-86 ${ }^{\circledR}$ (Arysta LifeScience North America, LLC) was used as experimental treatment. Göemar BM-86 is a standardized Ascophyllum nodosum (L.) Le Jolis extract, containing $\mathrm{N}-5.0 \%, \mathrm{Mg}-2.4 \%, \mathrm{~S}-3.2 \%, \mathrm{~B}-2.07 \%$, Mo $0.02 \%$ (https://www.arystalifescience.com/, 2018). Biostimulant was applied to all eggplant hybrids as foliar spraying (3-times, in a dose $1.5 \mathrm{dm}^{3} \mathrm{ha}^{-1}$ ), control plants were sprayed with distilled water. Sprayings were performed with backpack-type sprayer in similar weather conditions, conducive to the penetration of leaf tissues by the preparation (Kolomazník et al., 2012). First spraying was performed two weeks after transplanting the seedlings to the field, subsequent sprayings - in two-week intervals.

The experiment was established in 2013 and 2014 at the University of Agriculture in Krakow, southern Poland. Eggplant seeds were sown March 01, 2013 and March 03, 2014 in seed boxes filled with peat substrate KlasmanTS2 (Klasmann-Deilmann GmbH, Germany). The seedlings in the stage of first fully developed leaf, were transplanted into black 40-cell multipots (VEFI, Norway), the individual cell volume was $0.23 \mathrm{dm}^{3}$. The temperature in a greenhouse was maintained at the level $20 / 17 \pm 2{ }^{\circ} \mathrm{C}$ (day/night). The plants were two-times fertilised with Kristalon Green (Yara, Poland) in a dose of $10 \mathrm{~g} \mathrm{dm}^{-3}$ water in a form of foliar spraying. After 7 day-long gradual decrease in temperature and irrigation, seedlings were planted in mid-May 2013 and 2014, at the Vegetable Experimental Station of University of Agriculture in Krakow, Poland ( $50^{\circ} 04^{\prime} \mathrm{N}, 19^{\circ} 51^{\prime} \mathrm{E}$ ). The climate of the experimental station was humid and continental (Dfb, according to the Köppen's classification). The soil was classified as a Fluvic Cambisol (Humic) according to the FAO classification with a $\mathrm{C}_{\text {org }}$ level of $2 \%$ and $\mathrm{pH}_{\mathrm{KCl}} 6.11$. Seedlings were planted in the experimental field following a completely randomized block design experiment, three replications per a treatment, and standard horticultural practices (weeding, irrigation, pest and diseases control) for eggplant production in Poland. The spacing was $0.75 \times 0.6 \mathrm{~m}\left(2.2\right.$ plants per $\left.\mathrm{m}^{2}\right)$. The doses of fertilizers were calculated based on soil analyses to achieve a stable content of nutrients $\left(\mathrm{mg} \mathrm{dm}^{-3}\right): \mathrm{N}-100, \mathrm{P}-90, \mathrm{~K}-220, \mathrm{Ca}$ $-1,100$, and $\mathrm{Mg}-70$. Harvests were carried out from July to the end of September. 

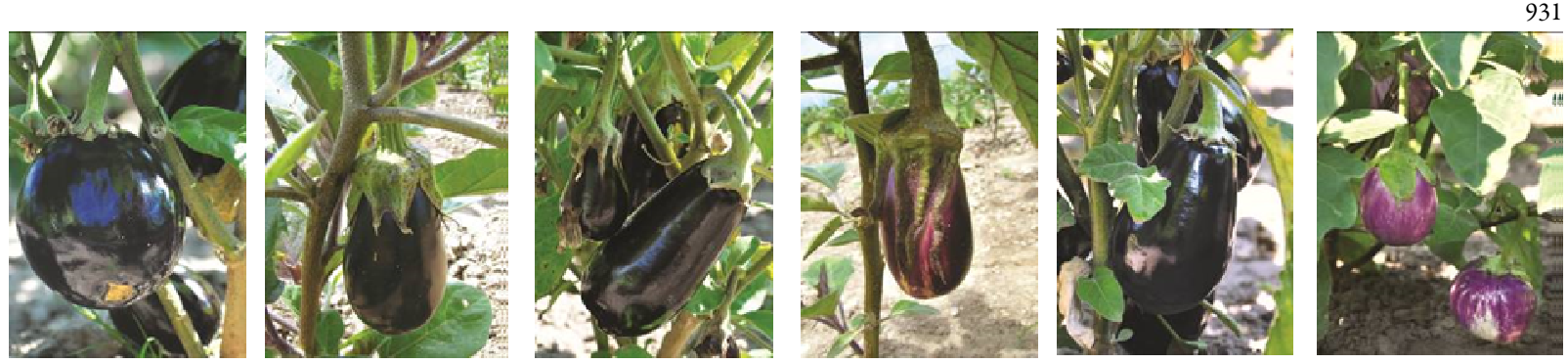

Fig. 1. Fruits of the six eggplant commercial $F_{1}$ hybrids evaluated (from the left: Cristal, Epic, Flavine, Gascona, Onyx, and WA 6020)

\section{Microclimate conditions in the field}

The air temperature, sum of rainfall was measured at $1 \mathrm{~h}$ intervals with the use of automatic sensors HOBO Pro $\mathrm{RH} / \mathrm{Temp}$ and daily photosynthetically active radiation (PAR) by HOBO Weather Station (Onset Comp. Corp., USA), localized at the experimental field. Data were presented as means for months of vegetation periods (Table 1).

Vegetation season of 2013 was characterised by higher mean month temperatures in May, June, and August, but July and September were cooler as compared to the second year of investigations. The highest PAR values were noted in July 2013 and in June 2014. In both years, September was a month with the lowest PAR radiation, as well as June in 2013. Rainfall was distributed more regularly in 2014, but the sum of rainfall for May-September period was similar in both experimental years, amounting 413 and $404 \mathrm{~mm}$, in 2013 and 2014, respectively.

\section{Determination of the yield}

Fruits in a stage of harvest maturity (as assessed by the size, colour and glossiness of the peel typical for a cultivar), were successively harvested and yield was assessed according to UNECE standard FFV-05 concerning the marketing and commercial quality control of aubergines (ECE/TRADE/C/WP.7/GE.1/2010/INF.37). Early yield, covering the first four harvests, marketable yield (both in $\mathrm{kg}$ $\mathrm{m}^{-2}$ ), the number of fruits taken from the plant, recalculated into fruits per $\mathrm{m}^{2}$, and average weight of the fruit were assessed.

\section{Determination of the fruit chemical composition}

Twenty fruits from each treatment, randomly collected during the full fruiting period, were the material for chemical analyses. Fruits were washed and grounded in a blender. Dry weight, total soluble sugars, and mineral contents were determined in whole fruits; anthocyanins were analysed in the fruit peel, antioxidant activity separately in fruit peel and flesh.
The dry weight content was determined by drying the sample at $105^{\circ} \mathrm{C}$ until constant weight was obtained. The measurements were performed with the use of Sartorius A120S scale (Sartorius AG, Germany).

For total soluble sugars determination, the anthrone method by Yemm and Willis (1954) was used. Plant material was mixed with $80 \%$ ethanol and anthrone reagent, than the absorbance was measured at $625 \mathrm{~nm}$ with Helios Beta spectrophotometer (Thermo Fisher Scientific Inc., USA).

The total antioxidant activity of eggplant peel and flesh was determined using 2,2-diphenyl-1-picrylhydrazyl (DPPH). Two and-a-half grams of peel were ground and dissolved with $80 \%$ methanol, and then samples were centrifuged $\left(10 \mathrm{~min}, 3492 \mathrm{~g}, 4^{\circ} \mathrm{C}\right)$. The mixture of $0.1 \mathrm{~cm}^{3}$ of decanted supernatant and $0.1 \mathrm{mM} \mathrm{DPPH}$ was dissolved with $4.9 \mathrm{~cm}^{3}$ of $80 \%$ methanol and incubated in dark $(15 \mathrm{~min}, 20$ $22^{\circ} \mathrm{C}$ ). The absorbance of mixture was measured at $517 \mathrm{~nm}$. The following formula was used to calculate DPPH radical scavenging activity: $\mathrm{AA}[\%]=\left[\left(\mathrm{A}_{0}-\mathrm{A}_{1}\right) / \mathrm{A}_{0}\right] \times 100 ; \mathrm{AA}$ - the antioxidant activity, $A_{0}$ - the absorbance of the reference solution, $A_{1}$ - the absorbance of the test solution (Molyneux, 2004).

Total anthocyanins were analyzed in the fruit peel. Plant material was milled and dissolved with $96 \%$ ethanol acidified with $1.5 \mathrm{M}$ hydrochloric acid (85:15, v/v). After incubation in a refrigerator $\left(4^{\circ} \mathrm{C}\right.$ for $\left.12 \mathrm{~h}\right)$, the absorbance of the sample was assessed at $528 \mathrm{~nm}$. The anthocyanin content was calculated using the molar absorption coefficient of $1 \%$ cyanidin-3-glucoside solution $\left(\varepsilon=5.59 \mathrm{dm}^{3} \mathrm{~mol}^{-1} \mathrm{~cm}^{-1}\right)$.

$\mathrm{P}$ was determined with colorimetric method. $\mathrm{Fe}, \mathrm{Zn}, \mathrm{Ca}$, and $\mathrm{Cu}$ contents were analysed using atomic absorption spectroscopy. Fruits were washed with distilled water, dried at $65^{\circ} \mathrm{C}$ for $24 \mathrm{~h}$, then were ground and homogenized. Samples of $5 \mathrm{~g}$ of dried material were mineralized at $500{ }^{\circ} \mathrm{C}$. The residue was dissolved in $1 \mathrm{~cm}^{3}$ of nitric acid $(1: 2 \mathrm{v} / \mathrm{v})$, made up into a volume of $25 \mathrm{~cm}^{3}$ with distilled water, elements were determined with the use of Varian SpectrAA 20 (Australia) in an air-acetylene flame under standard operating conditions (Jackson and Qiao, 1992).

Table 1. Mean month temperature, photosynthetically active radiation (PAR) and sum of rainfall in vegetation seasons 2013 and 2014

\begin{tabular}{ccccccc}
\hline \multirow{2}{*}{ Month } & \multicolumn{3}{c}{2013} & \multicolumn{2}{c}{2014} \\
\cline { 2 - 7 } & Temperature $\left({ }^{\circ} \mathrm{C}\right)$ & $\operatorname{PAR}\left(\mu \mathrm{mol} \mathrm{m}^{-2} \mathrm{~s}^{-1}\right)$ & Sum of rainfall $(\mathrm{mm})$ & Temperature $\left({ }^{\circ} \mathrm{C}\right)$ & $\operatorname{PAR}\left(\mu \mathrm{mol} \mathrm{m}^{-2} \mathrm{~s}^{-1}\right)$ & Sum of rainfall $(\mathrm{mm})$ \\
\hline May & 14.3 & 345 & 83 & 13.8 & 376 & 108 \\
June & 17.6 & 392 & 188 & 16.2 & 428 & 63 \\
July & 19.4 & 477 & 28 & 20.2 & 249 & 96 \\
August & 18.8 & 396 & 51 & 17.4 & 333 & 80 \\
September & 12.1 & 256 & 63 & 15.0 & 248 & 57 \\
\hline
\end{tabular}


932

\section{Statistical procedures}

Statistical analyses were performed in STATISTICA 12.0 (StatSoft, Inc., USA). A two-way analysis of variance and Tukey's HSD test were used to determine the main effects of biostimulant and genotype as well as interactions among main effects, at the significance level $\mathrm{p}<0.05\left(^{*}\right), \mathrm{p}<$ $\left.\left.0.01{ }^{(* *}\right), \mathrm{p}<0.001{ }^{(* *}\right)$, non-significant (n.s.). The principal component analysis (PCA) was used to assess the genetic diversity in the yield and biochemical traits. PC1 and $\mathrm{PC} 2$, were used for further analysis on a base of their eigenvalues. Cluster analysis was also performed, basing on Ward's method with Euclidean distance, variables were not standardized. Cultivars were clustered according to the values of investigated yield and biochemical parameters.

\section{Results and Discussion}

\section{Yield evaluation}

The early yield of investigated eggplant hybrids, covering first four harvests, was significantly higher in treatments with biostimulant application (Fig. 2). Biostimulant positively affected the total yield of 'Epic $F_{1}$ ' in 2014, 'Flavine' $F_{1}$, and 'WA 6020' $F_{1}$ in both years of investigations, as well as 'Gascona' $F_{1}$ in 2013. Regardless of the cultivar, the early and total yields in 2013 were higher by $48 \%$ and $13 \%$, respectively, in treatments with biostimulant application as compared to the control. In 2014, the differences amounted to $136 \%$ and 23\%. Analysis of genotypic-dependent differences in early and total yield regardless of biostimulant application, pointed 'Cristal' $\mathrm{F}_{1}$ 'Epic' $F_{1}$, 'Onyx' $F_{1}$, and 'WA 6020' $F_{1}$ as the hybrids of highest potential in respect to these features. Sivasankari et al. (2006), Roussos et al. (2009) and Ramya et al. (2015) demonstrated that foliar spraying with seaweed extracts accelerated vegetative development, flowering, and fructification of grapevine, strawberry, and eggplant, respectively. Referred authors listed that the main mechanism underlying improved crop development was phytohormones contained in seaweed extracts. According to Abd El-Gawad and Osman (2014), foliar application of seaweed extract regulated bio-physiological activities and maintained higher photosynthetic activity of eggplant leaves which resulted in an increase of productivity.

In both experimental years, mean fruit weight significantly increased as an effect of biostimulant application only for 'WA 6020' F F $_{1}$ (Fig. 3). The differences between Göemar BM-86 treatment and the control were non-significant for remaining cultivars. Biostimulant application caused the significant increase in the number of fruits for 'Epic' $F_{1}$ and 'Flavine' $F_{1}$ hybrids in 2014 (Fig. 4). The average fruit number for cultivars was higher by $11 \%$ in 2013 and 19\% in 2014 in biostimulant treated plants as compared to the control. The reaction of eggplant on Göemar BM-86 application was genotypic dependent. The increase of total yield, noted for 'Flavine' $F_{1}$ and 'WA 6020' $F_{1}$ in both years of investigations, as well as 'Gascona' $F_{1}$ in 2013 and 'Epic' $F_{1}$ in 2014 has different grounds. For 'Epic' $F_{1}$ it as affected by statistically confirmed higher fruit number harvested from the plant, probably similar mechanism can be linked to yield potential of 'Flavine' $F_{1}$ (confirmed statistically in 2014). In the case of 'WA 6020' $\mathrm{F}_{1}$, the increase of the yield could be affected by greater fruit weight, confirmed statistically in both experimental years. Preliminary investigations of Pohl et al. (2018) showed also more intensive fruit setting by 'Flavine' $\mathrm{F}_{1}$ caused by biostimulant application. Similar reaction was also observed for 'WA 6020' $F_{1}$ - the direct effect of biostimulant application was significantly greater fruit weight but not the number of fruits per plant. Dobromilska and Gubarewicz (2008) analysed the response of 'Conchita' $F_{1}$ tomato
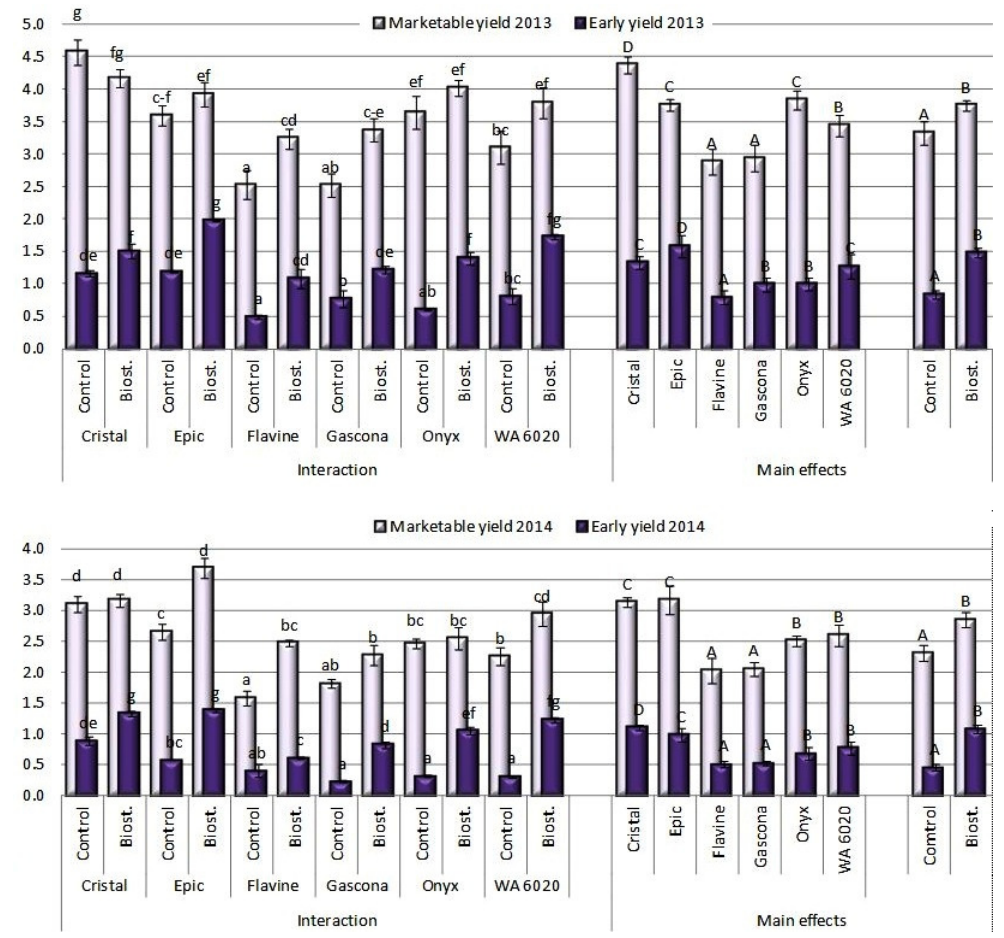

Fig. 2. The effect of cultivar and biostimulant treatment on early and marketable yield $\left(\mathrm{kg} \mathrm{m}^{-2}\right)$ of eggplant in 2013 and 2014 ; Data are means for three replications \pm SD. Different letters between cultivars and treatments denote significant differences, lowercase letters for interaction and capital letters for the main effects (Tukey's HSD test, $\mathrm{p}<0.05$ ) 


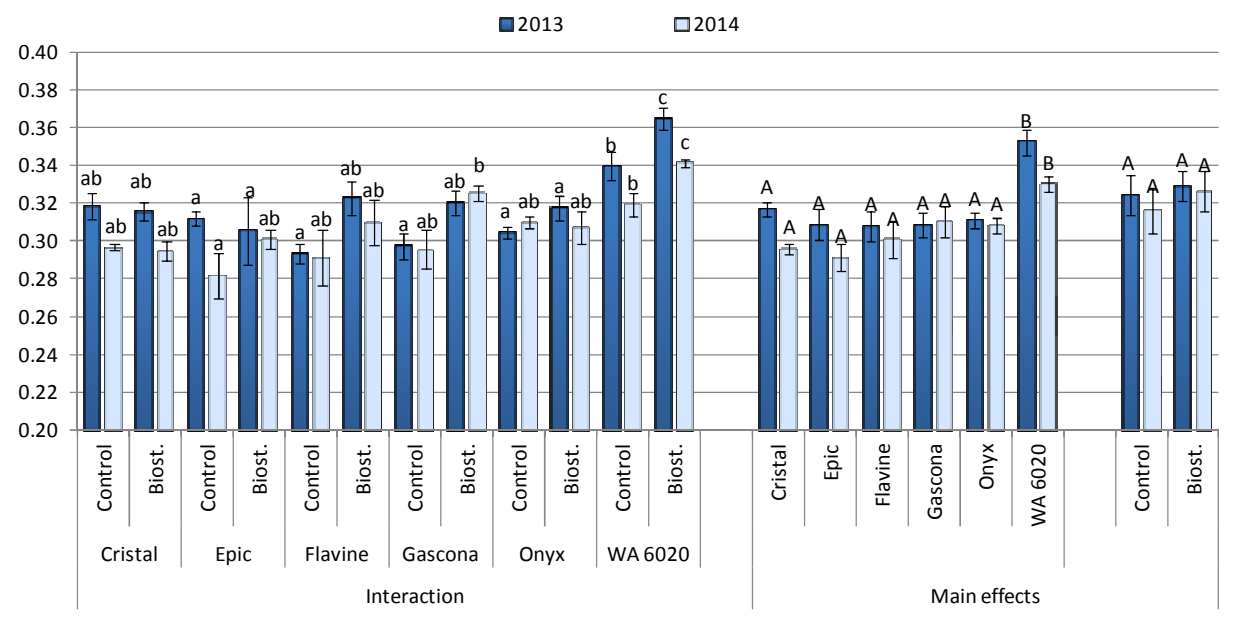

Fig. 3. The effect of biostimulant treatment on mean fruit weight $(\mathrm{kg})$ of eggplant cultivars in 2013 and 2014; Note: Data are means for three replications \pm SD. Different letters between cultivars and treatments denote significant differences, lowercase letters for interaction and capital letters for the main effects (Tukey's HSD test, $\mathrm{p}<0.05$ )

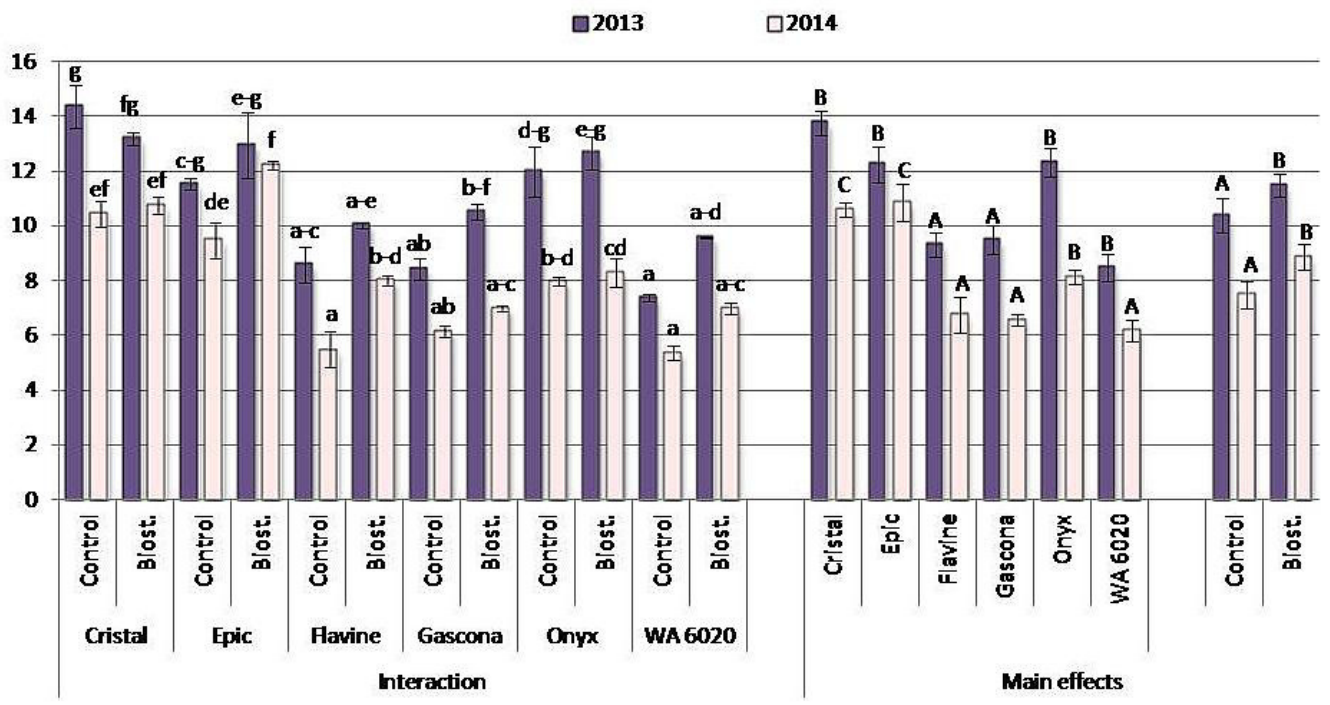

Fig. 4. The effect of biostimulant treatment on number of fruits per $\mathrm{m}^{2}$ of eggplant cultivars in 2013 and 2014; Note: Data are means for three replications \pm SD. Different letters between cultivars and treatments denote significant differences, lowercase letters for interaction and capital letters for the main effects (Tukey's HSD test, $\mathrm{p}<0.05$ )

against $A$. nodosum based Bio-algeen S-90. Plants treated with biostimulant set greater amount of fruits of smaller diameter, resulting in significant increase of total and marketable yield.

\section{Bioactive compounds in fruits}

Numerous authors pointed out the positive effect of $A$. nodosum extracts on tomato chemical composition, especially concerning sugars to acids ratio and vitamin $\mathrm{C}$ content (Dobromilska et al., 2008; Dobromilska and Gubarewicz, 2008; Kossak and Dyki, 2008). Analysis of interactions effects in the present experiment showed that biostimulant application significantly increased soluble sugar content in fruits of 'Cristal' $F_{1}$ and 'WA 6020' $F_{1}$ in both experimental years, as well as 'Epic' $F_{1}$, 'Flavine' $F_{1}$ and 'Onyx' $F_{1}$ in 2014 (Table 2). The highest sugar content was determined for 'Onyx' $F_{1}$ and 'WA 6020' $F_{1}$ : 3.67 and 3.95 grams per $100 \mathrm{~g} \mathrm{FW}$, respectively (mean for treatments and years). Total anthocyanins of fruit peel were not affected by interaction of experimental factors in 2013, but 'Cristal' $F_{1}$, 'Epic' $F_{1}$ and 'WA 6020' $F_{1}$ showed significant increase of this compounds caused by Göemar BM-86 application in 2014 , by $83 \%, 18 \%$, and $52 \%$, respectively. Cultivars characterized by the highest total anthocyanins contents were 'Epic' $F_{1}$, and 'Cristal' $F_{1}-3.36$ and 2.17 grams per 100 $\mathrm{gFW}$, respectively (mean for treatments and years).

The importance of eggplant as a dietary antioxidant source could be linked to the high content of phenolic acids in the fruit flesh and/or the anthocyanins in the peel (Sadilova et al., 2006; Tateyama and Igarashi, 2006; Sękara et al., 2015). Mean total antioxidant activity (TAA) of fruit peel and flesh of eggplant berries was similar: $8.07 \%$ and $7.50 \%$ DPPH; respectively in 2013, and $8.36 \%$ and $8.08 \%$ DPPH; respectively in 2014. Interactions between experimental factors caused significant increase of TAA of fruit peel for 'Cristal' $F_{1}$, 'Epic' $F_{1}$, 'Flavine' $F_{1}$ (2013 and 
934

2014) and 'WA 6020' $F_{1}$ (2014) due to biostimulant application. The increase of fruit flesh TAA was noted for 'Cristal' $F_{1}$, 'Gascona' $F_{1}$ (2013) and 'Cristal' $F_{1}$, 'Epic' $F_{1}$, and 'Gascona' $F_{1}$ (2014). Cultivars characterized by the highest TAA of peel were 'Flavine' $F_{1}$ and 'Epic' $F_{1}-13.83 \%$ and $9.89 \% \mathrm{DPPH}$, respectively (mean for treatments and years). According to San José et al. $(2013,2014)$ relatively high content of antioxidants, particularly phenolics, was determined in the flesh of eggplant fruit. Tateyama and Igarashi (2006) determined that TAA of eggplant extracts collected from cultivars with multi-colored fruits has depended mainly on the chlorogenic acid content. Our results might shed new light on the share of peel's anthocyanins and flesh's phenolics in total antioxidant activity of eggplant fruits of different colour. 'Flavine' $F_{1}$ and 'Epic' $F_{1}$, with dark-violet fruits, were characterized by highest TAA of fruit peel while 'Gascona' $F_{1}$ and 'WA $6020^{\prime} F_{1}$, with pink-violet fruits - showed the highest values of fruit flesh TAA.

\section{Mineral elements in fruits}

Many reports suggest that seaweed extracts can affect soil-plant interactions leading to increase plant nutrient status. Some mechanisms which can be involved in enhancing nutrient uptake include increased exchange capacity of soils, supplying minerals to the crops, enhancing the solubility of nutrients in soil solution, boosting the root growth and development that allows for better soil exploration and resource acquisition, increased activity of root system through up-regulation of the genes involved in the transport of nutrients, etc. (Vernieri et al., 2006; Jannin et al., 2013; De Pascale et al., 2017). Our study showed that the content of $\mathrm{P}, \mathrm{Fe}, \mathrm{Zn}, \mathrm{Ca}$, but not $\mathrm{Cu}$ in eggplant fruits was significantly affected by both experimental factors (Table 3). In 2013, biostimulant application increased $P$ level in fruits of 'Onyx' $F_{1}$, cultivar, in 2014 - in 'Cristal' $F_{1}$, 'Epic' $F_{1}$, 'Flavine' $F_{1}$, and 'Onyx' $F_{1}$. Regardless of biostimulant treatment, the best source of this element were fruits of 'Onyx' $F_{1}$ (2013) 'Epic' $F_{1}$ and 'WA 6020' $F_{1}$

Table 2. Chemical composition of eggplant fruits as affected by biostimulant treatment and genetic factor in 2013 and 2014

\begin{tabular}{|c|c|c|c|c|c|}
\hline Cultivar & $\begin{array}{c}\text { Treatment } \\
\text { (C - control; } \\
\text { B - biostimulant })\end{array}$ & 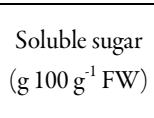 & $\begin{array}{c}\text { Total } \\
\text { anthocyanins } \\
\left.\text { (g } 100 \mathrm{~g}^{-1} \mathrm{FW}\right)\end{array}$ & $\begin{array}{c}\text { Total antioxidant } \\
\text { activity of peel } \\
\text { (\% DPPH) }\end{array}$ & $\begin{array}{c}\text { Total antioxidant } \\
\text { activity of flesh } \\
\text { (\% DPPH) }\end{array}$ \\
\hline & & \multicolumn{4}{|c|}{2013} \\
\hline \multirow{2}{*}{ Cristal } & $\mathrm{C}$ & $1.95 \mathrm{a}$ & 1.77 & $6.30 \mathrm{ab}$ & $2.87 \mathrm{a}$ \\
\hline & B & $3.48 \mathrm{bc}$ & 2.88 & $8.45 \mathrm{c}$ & $4.47 \mathrm{~b}$ \\
\hline \multirow{2}{*}{ Epic } & $\mathrm{C}$ & $3.00 \mathrm{~b}$ & 2.37 & $8.19 b c$ & $4.65 \mathrm{ab}$ \\
\hline & $\mathrm{B}$ & $3.29 \mathrm{~b}$ & 2.57 & $11.28 \mathrm{~d}$ & $6.48 \mathrm{~b}$ \\
\hline \multirow{2}{*}{ Flavine } & $\mathrm{C}$ & $3.33 \mathrm{~b}$ & 1.72 & $11.49 \mathrm{~d}$ & $7.82 \mathrm{~cd}$ \\
\hline & B & $3.36 \mathrm{~b}$ & 2.28 & $16.37 \mathrm{e}$ & $8.16 \mathrm{~cd}$ \\
\hline \multirow{2}{*}{ Gascona } & $\mathrm{C}$ & $3.10 \mathrm{~b}$ & 1.57 & $5.56 \mathrm{a}$ & $6.56 \mathrm{bc}$ \\
\hline & B & $3.43 b c$ & 2.40 & $6.27 \mathrm{ab}$ & $13.82 \mathrm{~g}$ \\
\hline \multirow{2}{*}{ Onyx } & $\mathrm{C}$ & $3.40 \mathrm{bc}$ & 2.45 & $5.67 a$ & $7.92 \mathrm{~cd}$ \\
\hline & B & $3.94 \mathrm{~cd}$ & 2.50 & $6.62 \mathrm{a}-\mathrm{c}$ & $8.96 \mathrm{de}$ \\
\hline \multirow{2}{*}{ WA 6020} & C & $3.53 b c$ & 1.57 & $4.65 \mathrm{a}$ & $10.89 \mathrm{ef}$ \\
\hline & $\mathrm{B}$ & $4.50 \mathrm{~d}$ & 2.40 & $6.01 \mathrm{a}$ & $12.26 \mathrm{fg}$ \\
\hline \multirow{3}{*}{ Source of variation } & Cultivar (CV) & $* * *$ & * & $* * *$ & $* * *$ \\
\hline & Biostimulant (B) & $* * *$ & $* * *$ & $* * *$ & $* * *$ \\
\hline & $\mathrm{CV} \times \mathrm{B}$ & $* * *$ & n.s. & $* * *$ & $* * *$ \\
\hline & & \multicolumn{4}{|c|}{2014} \\
\hline \multirow{2}{*}{ Cristal } & $\mathrm{C}$ & $2.49 a$ & $1.42 \mathrm{~b}$ & $6.23 \mathrm{ab}$ & $3.83 \mathrm{a}$ \\
\hline & B & $3.53 \mathrm{~cd}$ & $2.60 \mathrm{c}$ & $8.70 \mathrm{~d}$ & $6.01 \mathrm{~b}$ \\
\hline \multirow{2}{*}{ Epic } & C & $2.68 \mathrm{ab}$ & $3.88 \mathrm{~d}$ & $8.59 \mathrm{~cd}$ & $4.65 \mathrm{a}$ \\
\hline & $\mathrm{B}$ & $3.70 \mathrm{~cd}$ & $4.60 \mathrm{e}$ & $11.50 \mathrm{e}$ & $6.51 \mathrm{~b}$ \\
\hline \multirow{2}{*}{ Flavine } & C & $2.74 \mathrm{ab}$ & $2.28 \mathrm{c}$ & $11.29 \mathrm{e}$ & $8.30 \mathrm{c}$ \\
\hline & $\mathrm{B}$ & $3.44 \mathrm{c}$ & $2.50 \mathrm{c}$ & $16.17 \mathrm{f}$ & $8.44 \mathrm{c}$ \\
\hline \multirow{2}{*}{ Gascona } & $\mathrm{C}$ & $3.21 b c$ & $0.70 \mathrm{a}$ & $6.21 \mathrm{ab}$ & $6.29 \mathrm{~b}$ \\
\hline & $\mathrm{B}$ & $3.07 \mathrm{a}-\mathrm{c}$ & $1.33 \mathrm{ab}$ & $7.88 \mathrm{~b}-\mathrm{d}$ & $12.60 \mathrm{e}$ \\
\hline \multirow{2}{*}{ Onyx } & C & $3.26 b c$ & $2.30 \mathrm{c}$ & $6.12 \mathrm{ab}$ & $8.83 \mathrm{c}$ \\
\hline & B & $4.09 \mathrm{de}$ & $2.75 \mathrm{c}$ & $6.89 \mathrm{~b}-\mathrm{d}$ & $8.75 \mathrm{c}$ \\
\hline \multirow{2}{*}{ WA 6020} & $\mathrm{C}$ & $3.27 \mathrm{bc}$ & $1.40 \mathrm{~b}$ & $4.47 \mathrm{a}$ & $10.86 \mathrm{~d}$ \\
\hline & B & $4.51 \mathrm{e}$ & $2.13 \mathrm{c}$ & $6.37 \mathrm{bc}$ & $11.92 \mathrm{de}$ \\
\hline \multirow{3}{*}{ Source of variation } & Cultivar (CV) & $* * *$ & $* * *$ & $* * *$ & $* * *$ \\
\hline & Biostimulant (B) & *** & $* *$ & $* * *$ & $* * *$ \\
\hline & $\mathrm{CV} \times \mathrm{B}$ & $* * *$ & * & $* * *$ & $* * *$ \\
\hline
\end{tabular}




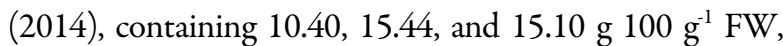
respectively. Fruits of 'Epic' $F_{1}$ (in 2013 and 2014), 'Gascona' $F_{1}$ (2013), and 'Onyx' $F_{1}$ (2014), harvested from plants treated with Göemar BM-86, were characterized by significantly higher level of $\mathrm{Fe}$ in comparison to the untreated control. Regardless of biostimulant treatment, 'Epic' $F_{1}$ fruits were the richest source of Fe. In the case of $\mathrm{Zn}$, significant differences between experimental treatments caused by interaction were determined only in 2013, and 'Flavine' $F_{1}$, 'Gascona' $F_{1}$, and 'WA 6020' $F_{1}$ showed higher content of this element in fruits treated with biostimulant. 'Epic' $F_{1}$ fruits contained the highest amount of this element among investigated cultivars. In 2013, the content of Ca was significantly higher in fruits of 'Epic' $F_{1}$, 'Flavine' $F_{1}$, and 'Gascona' $F_{1}$ treated with Göemar BM-86. In 2014 similar effect was determined only for 'Gascona' $F_{1}$. Interactions of experimental treatments was not significant in the case of $\mathrm{Cu}$. 'Cristal' $\mathrm{F}_{1}$ fruits contained the highest amount of $\mathrm{Ca}$ and $\mathrm{Cu}$ in both experimental years. Colla et al. (2017) determined that the application of seaweed extracts enhanced the $\mathrm{Ca}$ concentration in the tomato fruit tissue. Majkowska-Gadomska and Wierzbicka (2013) reported that biostimulant Asahi SL significantly increased $\mathrm{K}$ and $\mathrm{Cu}$ contents in two eggplant cultivars grown in unheated tunnels in northern Poland. $A$. nodosum preparations may enhance the accumulation of minerals through the influence of xylem transport of water and mineral salts. Kossak and Dyki (2008) described better developed vascular bundles of the stems of tomato plants treated with biostimulants. Increase of vascular transport effectiveness could improve conditions for photosynthesis and assimilates accumulation in eggplant fruits in conditions of present experiment, affecting also crop chemical composition and antioxidant status.

\section{Principal components and cluster analyses}

Understanding which traits contribute the most to the variation observed among trials is very important for

Table 3. Mineral elements in eggplant fruits as affected by biostimulant treatment and genetic factor in 2013 and 2014

\begin{tabular}{|c|c|c|c|c|c|c|}
\hline \multirow[t]{2}{*}{ Cultivar } & $\begin{array}{c}\text { Treatment } \\
(\mathrm{C} \text { - control; } \\
\text { B - biostimulant })\end{array}$ & $\mathrm{P}$ & $\mathrm{Fe}$ & $\mathrm{Zn}$ & $\mathrm{Ca}$ & $\mathrm{Cu}$ \\
\hline & & $\left({\left.\mathrm{g} ~ 100 \mathrm{~g}^{-1} \mathrm{FW}\right)}\right.$ & \multicolumn{4}{|c|}{$\left(\mathrm{mg} 100 \mathrm{~g}^{-1} \mathrm{FW}\right)$} \\
\hline & & & & 2013 & & \\
\hline \multirow{2}{*}{ Cristal } & $\mathrm{C}$ & $8.63 \mathrm{ab}$ & $0.271 \mathrm{ab}$ & $0.165 \mathrm{a}$ & $0.223 \mathrm{~b}-\mathrm{d}$ & 0.109 \\
\hline & B & $9.50 \mathrm{ab}$ & $0.357 \mathrm{~b}-\mathrm{d}$ & $0.186 \mathrm{ab}$ & $0.226 \mathrm{~b}-\mathrm{d}$ & 0.120 \\
\hline \multirow{2}{*}{ Epic } & $\mathrm{C}$ & $8.70 \mathrm{ab}$ & $0.330 \mathrm{a}-\mathrm{c}$ & $0.362 \mathrm{~d}$ & $0.169 \mathrm{ab}$ & 0.078 \\
\hline & B & $9.15 \mathrm{ab}$ & $0.612 \mathrm{e}$ & $0.364 \mathrm{~d}$ & $0.268 \mathrm{de}$ & 0.082 \\
\hline \multirow{2}{*}{ Flavine } & C & $8.14 \mathrm{a}$ & $0.397 \mathrm{~b}-\mathrm{d}$ & $0.249 \mathrm{bc}$ & $0.148 \mathrm{a}$ & 0.078 \\
\hline & B & $9.59 \mathrm{ab}$ & $0.390 \mathrm{~b}-\mathrm{d}$ & $0.363 \mathrm{~d}$ & $0.301 \mathrm{e}$ & 0.090 \\
\hline \multirow{2}{*}{ Gascona } & $\mathrm{C}$ & $9.12 \mathrm{ab}$ & $0.214 \mathrm{a}$ & $0.252 \mathrm{c}$ & $0.154 \mathrm{a}$ & 0.074 \\
\hline & B & $10.52 \mathrm{bc}$ & $0.462 \mathrm{c}$ & $0.346 \mathrm{~d}$ & 0.259 de & 0.095 \\
\hline \multirow{2}{*}{ Onyx } & C & $8.70 \mathrm{ab}$ & $0.277 \mathrm{ab}$ & $0.155 \mathrm{a}$ & $0.142 \mathrm{a}$ & 0.104 \\
\hline & B & $12.09 \mathrm{c}$ & $0.370 \mathrm{~b}-\mathrm{d}$ & $0.177 \mathrm{a}$ & $0.194 \mathrm{a}-\mathrm{c}$ & 0.115 \\
\hline \multirow{2}{*}{ WA 6020} & $\mathrm{C}$ & $9.73 \mathrm{ab}$ & $0.368 \mathrm{~b}-\mathrm{d}$ & $0.177 \mathrm{a}$ & $0.149 a$ & 0.093 \\
\hline & B & $10.31 \mathrm{bc}$ & $0.429 \mathrm{~cd}$ & $0.362 \mathrm{~d}$ & $0.247 \mathrm{c}-\mathrm{e}$ & 0.105 \\
\hline \multirow{3}{*}{$\begin{array}{l}\text { Source of } \\
\text { variation }\end{array}$} & Cultivar $(\mathrm{CV})$ & $* * *$ & $* * *$ & ${ }^{* * *}$ & $* * *$ & ${ }^{* * *}$ \\
\hline & Biostimulant (B) & *** & $* * *$ & $* * *$ & $* * *$ & *** \\
\hline & $\mathrm{CV} \times \mathrm{B}$ & ** & $* * *$ & $* * *$ & $* * *$ & n.s. \\
\hline & & \multicolumn{5}{|c|}{2014} \\
\hline \multirow{2}{*}{ Cristal } & $\mathrm{C}$ & $13.19 \mathrm{a}-\mathrm{c}$ & $0.218 \mathrm{a}-\mathrm{d}$ & 0.078 & $0.227 b c$ & 0.045 \\
\hline & B & $16.04 \mathrm{~d}$ & $0.238 \mathrm{a}-\mathrm{d}$ & 0.087 & $0.263 \mathrm{~cd}$ & 0.053 \\
\hline \multirow{2}{*}{ Epic } & $\mathrm{C}$ & $11.58 \mathrm{a}$ & $0.311 \mathrm{de}$ & 0.079 & $0.146 \mathrm{a}-\mathrm{c}$ & 0.022 \\
\hline & B & $19.29 \mathrm{~d}$ & $0.611 \mathrm{~g}$ & 0.085 & $0.181 \mathrm{a}-\mathrm{c}$ & 0.029 \\
\hline \multirow{2}{*}{ Flavine } & C & $11.35 \mathrm{a}$ & $0.366 \mathrm{ef}$ & 0.074 & $0.125 \mathrm{ab}$ & 0.029 \\
\hline & B & $14.02 \mathrm{~b}-\mathrm{d}$ & $0.259 \mathrm{~b}-\mathrm{e}$ & 0.082 & $0.195 \mathrm{a}-\mathrm{c}$ & 0.031 \\
\hline \multirow{2}{*}{ Gascona } & C & $11.64 \mathrm{ab}$ & $0.463 \mathrm{f}$ & 0.088 & $0.099 \mathrm{a}$ & 0.035 \\
\hline & B & $11.66 \mathrm{ab}$ & $0.462 \mathrm{f}$ & 0.101 & $0.363 \mathrm{~d}$ & 0.038 \\
\hline \multirow{2}{*}{ Onyx } & $\mathrm{C}$ & $11.90 \mathrm{ab}$ & $0.122 \mathrm{a}$ & 0.105 & $0.177 \mathrm{a}-\mathrm{c}$ & 0.042 \\
\hline & B & $15.74 \mathrm{~d}$ & $0.270 \mathrm{c}-\mathrm{e}$ & 0.107 & $0.260 \mathrm{~cd}$ & 0.048 \\
\hline \multirow{2}{*}{ WA 6020} & $\mathrm{C}$ & $14.89 \mathrm{~cd}$ & $0.257 \mathrm{~b}-\mathrm{e}$ & 0.099 & $0.132 \mathrm{ab}$ & 0.042 \\
\hline & B & $15.31 \mathrm{~cd}$ & $0.429 \mathrm{~cd}$ & 0.105 & $0.176 \mathrm{a}-\mathrm{c}$ & 0.047 \\
\hline Source of & Cultivar (CV) & $* * *$ & ${ }^{* * *}$ & *** & $* * *$ & ${ }^{* * *}$ \\
\hline \multirow[t]{2}{*}{ variation } & Biostimulant (B) & *** & $* * *$ & ${ }^{* * *}$ & $* * *$ & $* * *$ \\
\hline & $\mathrm{CV} \times \mathrm{B}$ & *** & $* * *$ & n.s. & $* * *$ & n.s. \\
\hline
\end{tabular}

Note: Different letters between cultivars and treatments denote significant differences (Tukey's HSD test, ${ }^{*} \mathrm{p}<0.05 ;{ }^{* *} \mathrm{p}<0.01 ;{ }^{* * *} \mathrm{p}<0.001$; n.s. non-significant) 
936

Table 4. Coefficients for yield and biochemical traits contributing to the two leading principal components and proportion of total variance explained by the principal components analysis

\begin{tabular}{cccc}
\hline \multirow{2}{*}{ Trays } & & & Principal components coefficients \\
& & PC 1 & PC 2 \\
\cline { 2 - 4 } Yield & Early yield & 0.972 & -0.082 \\
trays & Total yield & 0.899 & 0.127 \\
& No of fruits & 0.882 & -0.446 \\
& Fruit weight & 0.394 & 0.907 \\
\hline & Variability \% & 67.22 & 26.11 \\
\hline \multirow{3}{*}{ Biochemical } & TAA peel & 0.010 & -0.332 \\
trays & TAA flesh & -0.203 & -0.557 \\
& Soluble sugars & -0.130 & -0.754 \\
& Anthocyanins & 0.205 & -0.505 \\
& $\mathrm{P}$ & 0.756 & -0.545 \\
& $\mathrm{Fe}$ & -0.301 & -0.615 \\
& $\mathrm{Zn}$ & -0.901 & -0.103 \\
& $\mathrm{Ca}$ & -0.356 & -0.407 \\
\hline
\end{tabular}

practical application of biostimulant for particular plant cultivar. Clustering of different eggplant cultivars according to morphological as well as biochemical traits was reported by Hurtado et al. (2012), Cericola et al. (2013), Augustinos et al. (2017).

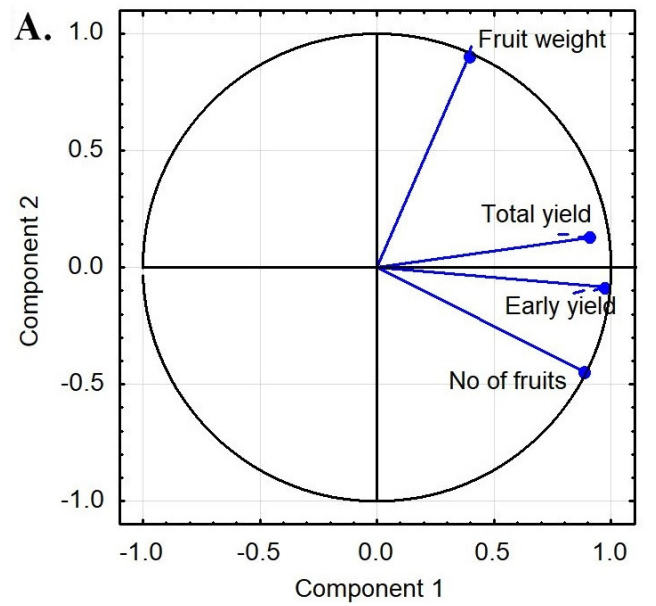

Fig. 5. Principal components projection for the investigated yield (A) and fruit composition trays (B)

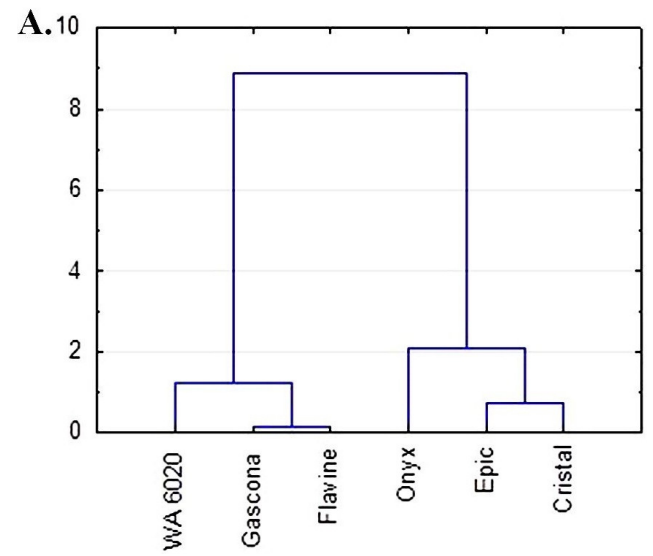

Fig. 6. Dendrogram analysis of $R$. canina accessions based on the yield (A) and fruit composition (B) trays (after Ward's method)
In the present experiment PCA showed that the first component covered $33.1 \%$ of the total variance, and the most important trials for separating the cultivars were related to fruit yield (total and early yield and number of fruits) and element ( $\mathrm{Zn}, \mathrm{Ca}, \mathrm{Cu}$ ) composition (Table 4, Fig.

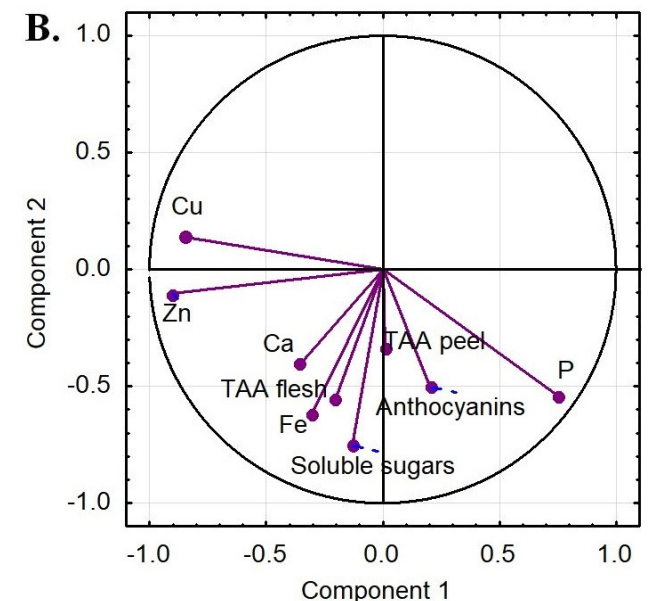

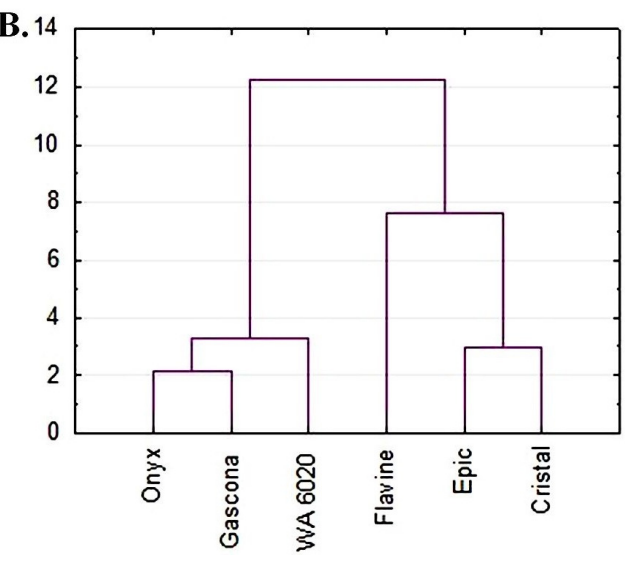

B. 
5). Moreover, as shown in the Ward's dendrograms, two major clusters were formed as an effect of separate analysis for yield and biochemical traits. In the both cases 'Cristal' $F_{1}$ and 'Epic' $F_{1}$ were clustered together as characterized by the best parameters determining the yield and its quality.

\section{Conclusions}

Seaweed extracts are precious source of bioactive compounds, but the knowledge about the effects of their application in eggplant crop management is still limited to few algae species applied to a narrow number of cultivars as well as growing systems. Seaweed extract can be an additional source of macro- and microelements, stimulators of nutrient uptake from the soil, elicitors of self-defence systems, can trigger the early flowering and fruiting, and may affect chemical composition of eggplant fruits. We showed that Ascophyllum nodosum standardized extract can enhance eggplant productivity and fruit quality in field conditions of Poland, but the response to biostimulant was significantly diversified between cultivars. The potential of eggplant hybrids upgraded by biostimulant application could be successfully exploited for enriching the European vegetable market in high quality and healthy products corresponding with consumer demands.

\section{Acknowledgements}

This work was supported by the Ministry of Science and Higher Education of the Republic of Poland.

\section{Conflict of Interest}

The authors declare that there are no conflicts of interest related to this article.

\section{References}

Abd El-Gawad HG, Osman HS (2014). Effect of exogenous application of boric acid and seaweed extract on growth, biochemical content and yield of Eggplant. Journal of Horticultural Science \& Ornamental Plants 6:133-143.

Arthur GD, Stirk WA, Van Staden J (2003).Effect of a seaweed concentrate on the growth and yield of three varieties of Capsicum annuum. South African Journal of Botany 69(2):207-211.

Arysta Lifescience (2018). Arysta Lifescience. Retrieved 2018 December 23 fromhttps://www.arystalifescience.com.

Augustinos AA, Petropoulos C, Karasoulou V, Bletsos F, Papasotiropoulos $\mathrm{V}$ (2017). Assessing diversity among traditional Greek and foreign eggplant cultivars using molecular markers and morphometrical descriptors. Spanish Journal of Agricultural Research 14(4):e0710.

Brown P, Saa $S$ (2015). Biostimulants in agriculture. Frontiers in Plant Science 6:671.

Cericola F, Portis E, Toppino L, Barchi L, Acciarri N, Ciriaci T, ... Lanteri S (2013). The population structure and diversity of eggplant from Asia and the Mediterranean Basin. PLoSOne 8(9):e73702.

Colla G, Rouphael Y (2015). Biostimulants in horticulture. Scientia
Horticulturae 196:1-2

Colla G, Cardarelli M, Bonini P, Rouphael Y (2017). Foliar applications of protein hydrolysate, plant and seaweed extracts increase yield but differentially modulate fruit quality of greenhouse tomato. HortScience 52(9):1214-1220.

Davis DR (2009). Declining fruit and vegetable nutrient composition: What is the evidence? HortScience 44(1):15-19.

De Pascale S, Rouphael Y, Colla G (2017). Plant biostimulants: innovative tool for enhancing plant nutrition in organic farming. European Journal of Horticultural Science 82:277-285.

Dobromilska R, Gubarewicz K (2008). Influence of Bio-algeen S-90 on the yield and quality of small-sized tomato. In: Dabrowski ZT (Ed). Biostimulators in Modern Agriculture: Solanaceous Crops. The Editorial House Wies Jutra, Warsaw, Poland pp 7-12.

Dobromilska R, Mikiciuk M, Gubarewicz K (2008). Evaluation of cherry tomato yielding and fruit mineral composition after using of Bio-algeen S-90preparation.Journal of Elementology 13(4):491-499.

Du Jardin P (2015). Plant biostimulants: definition, concept, main categories and regulation. Scientia Horticulturae 196:3-14.

Hernández-Herrera RM, Santacruz-Ruvalcaba F, Ruiz-López MA, NorrieJ, Hernández-Carmona G (2014). Effect of liquid seaweed extracts on growth of tomato seedlings (Solanum lycopersicum L.). Journal of Applied Phycology 26(1):619-628.

Hurtado M, Vilanova S, Plazas M, Gramazio P, Fonseka HH, Fonseka R, Prohens J (2012). Diversity and relationships of eggplants from three geographically distant secondary centers of diversity. PLOS One 7(7):e41748.

Jackson KW, Qiao H (1992). Atomic-absorption, atomic emission, and flame emission-spectrometry. Analytical Chemistry 64(12):50-66.

Jannin L, Arkoun M, Etienne P, Lainé P, Goux D, Garnica M, ... Houdusse F (2013). Brassica napus growth is promoted by Ascophyllum nodosum (L.) Le Jol. Seaweed extract: microarray analysis and physiological characterization of N, C, and S metabolisms. Journal of Plant Growth Regulation 32(1):31-52.

Khan W, Rayirath UP, Subramanian S, Jithesh MN, Rayorath P, Hodges DM, ... Prithiviraj B (2009). Seaweed extracts as biostimulants of plant growth and development. Journal of Plant Growth Regulation 28(4):386-399.

KolomazníkK, Pecha J, Friebrová V,JanáčováD, Vašek V(2012).Diffusion of biostimulators into plant tissues. Heat Mass Transfer 48(9):15051512.

Kossak K, Dyki B (2008). Effects of biostimulators on cultivation of Alboney $\mathrm{F}_{1}$ greenhouse tomato. In: Dabrowski ZT (Ed). Biostimulators in Modern Agriculture: Solanaceous Crops. The Editorial House Wies Jutra, Warsaw, Poland pp 13-20.

Kumar G, Meena BL, Kar R, Tiwari SK, Gangopadhyay KK, Bisht IS, Mahajan RK (2008). Morphological diversity in brinjal (Solanum melongena L.) germplasm accessions. Plant Genetic Resources: Characterization and Utilization 6(3):232-236.

Majkowska-Gadomska J, Wierzbicka B (2013). Effect of the biostimulator Asahi SL on the mineral content of eggplants (Solanum melongena L.) grown in an unheated plastic tunnel. Journal of Elementology 18(2):269-276. 
938

Manna D, Sarkar A, Maity TK (2012). Impact of biozyme on growth, yield and quality of chilli (Capsicum annuum L.). Journal of Crop and Weed 8:40-43.

Mennella G, Rotino GL, Fibiani M, D’Alessandro A, Francese G, Toppino L, ... Rotino GL (2010). Characterization of health-related compounds in eggplant (Solanum melongena $\mathrm{L}$.) lines derived from introgression of allied species. Journal of Agricultural and Food Chemistry 58(13):75977603.

Molyneux P (2004). The use of the stable free radical diphenylpicrylhydrazyl (DPPH) for estimating antioxidant activity. Songklanakarin Journal of Science and Technology 26(2):211-219.

Pohl A, Grabowska A, Kalisz A, Sękara A (2018). Preliminary screening of biostimulative effects of Göemar BM-86 on eggplant cultivars grown under field conditions in Poland. Acta Agrobotanica 71(4):1752.

Raigón MD, Rodríguez-Burruezo A Prohens J (2010).Effects of organic and conventional cultivation methods on composition of eggplant fruits. Journal of Agricultural and Food Chemistry 58(11):6833-6840.

Ramya SS, Vijayanand N, Rathinavel S (2015). Foliar application of liquid biofertilizer of brown alga Stoechospermum marginatum on growth, biochemical and yield of Solanum melongena. International Journal of Recycling ofOrganic Waste in Agriculture 4(3):167-173.

Rao GN, Chatterjee R (2014). Effect of seaweed liquid fertilizer from Gracilaria textorii and Hypnea musciformis on seed germination and productivity of some vegetable crops. Universal Journal of Plant Science 2(7):115-120.

Rodríguez-Burruezo A, Prohens J, Nuez F (2008). Performance of hybrids between local varieties of eggplant (Solanum melongena) and its relation to the mean of parents and to morphological and genetic distances among parents. European Journal of Horticultural Science 73(2):76-83.

Roussos PA, Denaxa N, Damvakaris T (2009). Strawberry fruit quality attributes after application of plant growth stimulating compounds. ScientiaHorticulturae 119(2):138-146.

Sadilova E, Stintzing FC, Carle R (2006). Anthocyanins, colour and antioxidant properties of eggplant (Solanum melongena $\mathrm{L}$.) and violet pepper (Capsicum annuum L.) peel extracts. Zeitschrift für Naturforschung C61(7-8):527-535.

San José R, Sánchez MC, Cámara MM, Prohens J (2013). Composition of eggplant cultivars of the occidental type and implications for the improvement of nutritional and functional quality. International Journal ofFood Science \& Technology 48(12):2490-2499.
San José R, Sánchez-Mata MC, Cámara M, ProhensJ (2014). Eggplant fruit composition as affected by the cultivation environment and genetic constitution. Journal of the Science of Food and Agriculture 94(13):2774-2784.

Sękara A (2010). Biology of the vegetative and generative development of eggplant (Solanum melongena L.) in the field production. Chosen aspects. Zeszyty Naukowe UR 459(336):1-109.

Sękara A, Bączek-Kwinta R, Gawęda M, Kalisz A, Pokluda R, Jezdinský A (2016). Sequential abiotic stress applied to juvenile eggplant modifies the seedlings parameters, plant ontogeny and yield. Horticultural Science (Prague) 43(3):149-157.

Sękara A, Kalisz A, Bączek-Kwinta R, Gawęda M, Pohl A, Grabowska A (2015). The effect of abiotic stresses applied in the juvenile phase of eggplant ontogeny on chemical composition of seedlings and fruits. Agrochimica 59(1):26-39.

Sharma HS, Fleming C, Selby C, Rao JR, Martin T (2014). Plant biostimulants: a review on the processing of macroalgae and use of extracts for crop management to reduce abiotic and biotic stresses. Journal of Applied Phycology 26(1):465-90.

Sivasankari S, Venkatesalu V, Anantharaj M, Chandrasekaran M (2006). Effect of seaweed extracts on the growth and biochemical constituents of Vignasinensis. Bioresource Technology 97(14):1745-1751.

Tateyama C, Igarashi K (2006). Anthocyanin and chlorogenic acid contents of some selected eggplant (Solanum melongena L.) cultivars, and the radical scavenging activities of their extracts. Journal of the Japanese Society for Food Science and Technology 53(4):218-224.

Vernieri P, Borghesi E, Tognoni F, Serra G, Ferrante A, Piagessi A (2006). Use of biostimulants for reducing nutrient solution concentration in floating system. Acta Horticulltuare 718:477-484.

Yakhin OI, Lubyanov AA, Yakhin IA (2017). Biostimulants in plant science: aglobal perspective. Frontiers in Plant Science 7:2049.

Yemm EW, Willis AJ (1954). The estimation of carbohydrates in plant extracts byanthrone. Biochemical Journal 57(3):508-514. 